\title{
Neuroendocrine Proopiomelanocortin Neurons Are Excited by Hypocretin/Orexin
}

\author{
Claudio Acuna-Goycolea and Anthony N. van den Pol \\ Department of Neurosurgery, Yale Medical School, New Haven, Connecticut 06520
}

\begin{abstract}
Hypocretin/orexin, produced by a group of neurons in the lateral hypothalamus/perifornical area, enhances cognitive arousal and also may play a crucial role in modulating the neuroendocrine system. How hypocretin modulates the endocrine system remains an open question. Hypocretin cells innervate the mediobasal hypothalamus where they can potentially influence the activity of specific cell populations within the arcuate nucleus. Here, we examine whether hypocretin modulates the median eminence-projecting proopiomelanocortin (POMC) neurons identified by selective green fluorescent protein expression and antidromic stimulation or retrograde Evans blue dye tracing in transgenic mice. We find that POMC neurons, in general, and, in addition, those that project their axons to the median eminence, were robustly activated by hypocretin in a dose-dependent manner. These excitatory actions included a threefold increase in spike frequency and direct membrane depolarization of up to $22 \mathrm{mV}$ (mean, $17.9 \pm 7.2 \mathrm{mV}$ ). Direct postsynaptic depolarization was decreased at more positive membrane potentials, inhibited by the sodium-calcium exchanger antagonist KB-R7943, and reduced by lowering the bath temperature, or by buffering the postsynaptic calcium with BAPTA, suggesting that the primary mechanism for hypocretin-mediated excitation is the activation of the sodium-calcium exchanger. Hypocretin also enhanced excitatory inputs to POMC cells via a presynaptic mechanism and indirectly increased the release of GABA onto these cells in a spike-dependent manner. However, these synaptic actions were not necessary to cause postsynaptic membrane depolarization and spiking. Thus, in contrast to previous suggestions that hypocretin inhibited POMC cells, our results demonstrate robust direct excitation of POMC neurons by hypocretin.
\end{abstract}

Key words: arcuate nucleus; glutamate; postsynaptic; food intake; hypothalamus; peptidergic

\section{Introduction}

Hypocretin neurons in the lateral hypothalamus/perifornical area play an important role in enhancing arousal (Chemelli et al., 1999; Hagan et al., 1999; Lin et al., 1999; Nishino et al., 2000; Thannickal et al., 2000; Sakurai, 2007), feeding (Sakurai et al., 1998; Hara et al., 2001; Willie et al., 2001), and neuroendocrine function (Date et al., 1999; Ida et al., 2000; Jászberényi et al., 2000; Al-Barzanji et al., 2001; Russell et al., 2001; Samson et al., 2002; Ferguson and Samson, 2003; Sakamoto et al., 2004; Spinazzi et al., 2006). During the last decade, the cellular bases for hypocretin regulation of sleep and energy homeostasis have been studied extensively, but the mechanisms underlying its neuroendocrine actions remain poorly understood.

Central administration of hypocretin can increase the release of several hormones from endocrine cells in the anterior pituitary (Ida et al., 2000; Jászberényi et al., 2000; Al-Barzanji et al., 2001; Russell et al., 2001; Sakamoto et al., 2004). The secretion of hormones within the pituitary is tightly regulated by factors secreted by neuroendocrine cells from the basal hypothalamus, including those in the arcuate nucleus. Here, specialized neuron subtypes

Received 0ct. 24, 2008; revised Dec. 10, 2008; accepted Dec. 20, 2008

This work was supported by National Institutes of Health Grants NS34887, NS48476, and NS41454. We thank V. Rogulin and Y. Yang for expert technical assistance.

Correspondence should be addressed to Anthony N. van den Pol, Department of Neurosurgery, Yale University School of Medicine, 333 Cedar Street, New Haven, CT 06520. E-mail: anthony.vandenpol@yale.edu. D01:10.1523/JNEUROSC1.5147-08.2009

Copyright $\odot 2009$ Society for Neuroscience $\quad$ 0270-6474/09/291503-11\$15.00/0 project axons into the median eminence (ME) where they release factors that regulate anterior pituitary hormone release. Thus, one possible explanation for the neuroendocrine actions of hypocretin could be that it modulates neuroendocrine neuron electrical activity within the arcuate nucleus.

Hypocretin cells send prominent projections to the arcuate nucleus (Peyron et al., 1998; van den Pol et al., 1998; Horvath et al., 1999) where hypocretin receptors are highly expressed (Lu et al., 2000; Hervieu et al., 2001; Marcus et al., 2001; Bäckberg et al., 2002). Within the arcuate, a number of chemically distinct cell populations have been identified, including the proopiomelanocortin (POMC) neurons (Schwartz et al., 2000). A number of independent lines of evidence suggest that hypocretin may modulate neuroendocrine function via regulation of POMC neuron activity. First, axon terminals containing hypocretins are found near arcuate POMC neurons (Horvath et al., 1999; Guan et al., 2001). Second, both immunohistochemical (Bäckberg et al., 2002) and calcium imaging (Muroya et al., 2003) experiments suggest that hypocretin receptors are expressed by POMC neurons. Third, the peptides $\alpha$-MSH and cocaine amphetamine regulated transcript (CART), produced by POMC cells, are expressed in axon terminals in the ME, are released into the portal blood, and can enhance pituitary hormone release, similar to hypocretins (Conover et al., 1993; Contijoch et al., 1993; Prasad et al., 1993; Larsen et al., 2003). Thus, neuroendocrine POMC neurons in the arcuate nucleus appear to be good candidates to mediate some of hypocretin's actions on hormone release from the anterior pituitary. 
Here, we study whether hypocretin can affect the activity of neuroendocrine POMC cells in the basal hypothalamus. In contrast to a previous report suggesting that hypocretin inhibits POMC cells (Ma et al., 2007), we found that hypocretin robustly excites POMC cells, including median-eminence-projecting neurons by both direct and indirect mechanisms. Importantly, although presynaptic mechanisms may play a role in modulating POMC activity, postsynaptic actions alone were sufficient to depolarize these neurons by up to $22 \mathrm{mV}$ and increase their firing rate by severalfold. Our results suggest that one mechanism whereby hypocretin peptides may regulate hormone secretions from the anterior pituitary is by the strong direct excitation of neuroendocrine POMC neurons.

\section{Materials and Methods}

\section{Animals and slice preparation}

A few experiments (see Fig. 1) were performed in wild-type mice. For all the other experiments, POMC-green fluorescent protein (GFP) transgenic mice (kindly provided by Dr. M. Low, Vollum Institute, Portland, OR) were used. These transgenic animals selectively express GFP under the control of the POMC promoter in POMC neurons, as described and characterized previously (Cowley et al., 2001; Batterham et al., 2002; Heisler et al., 2006; Münzberg et al., 2007). Two- to five-week-old mice were deeply anesthetized with sodium pentobarbital $(100 \mathrm{mg} / \mathrm{kg})$. Their brains were quickly removed and placed in ice-cold, oxygenated $(95 \%$ oxygen $/ 5 \% \mathrm{CO}_{2}$ ) high-sucrose solution containing (in mM) 220 sucrose, $2.5 \mathrm{KCl}, 6 \mathrm{MgCl}_{2}, 1 \mathrm{CaCl}_{2}, 1.25 \mathrm{NaH}_{2} \mathrm{PO}_{4}, 26 \mathrm{NaHCO}_{3}$, and 10 glucose ( $\approx 315 \mathrm{mOsm}$ ). A block of brain tissue containing the basal hypothalamus was gently dissected out, transferred to a vibratome, where $250 \mu \mathrm{m}$ transverse slices were cut, and moved to an equilibrium chamber filled with oxygenated artificial CSF (ACSF) that contained (in mM) $124 \mathrm{NaCl}$, $3 \mathrm{KCl}, 1 \mathrm{MgCl}_{2}, 2 \mathrm{CaCl}_{2}, 1.23 \mathrm{NaH}_{2} \mathrm{PO}_{4}, 26 \mathrm{NaHCO}_{3}$, and 10 glucose. In some experiments, as indicated in Results, we used 5 or $2 \mathrm{~mm}$ external glucose. The alterations in ASCF osmolarity associated with changing external glucose concentration were compensated for by adding osmotically equivalent amounts of sucrose to the external buffer. After $1-2 \mathrm{~h}$ of recovery, brain slices with an intact $\mathrm{ME}$ and arcuate nucleus were placed in the recording chamber mounted on an Olympus BX51WI microscope equipped with differential interference contrast (DIC) and fluorescence capabilities. The tissue was constantly perfused with oxygenated ACSF at $\sim 5 \mathrm{ml} / \mathrm{min}$.

\section{Electrophysiological recordings}

GFP-expressing cells in the arcuate were identified under fluorescence and approached under DIC. In some experiments, cell-attached recordings were performed by gently placing the recording pipette (filled with normal ACSF) in the proximity of the target cell, thereby establishing a low resistance seal (usually $\sim 50 \mathrm{M} \Omega$ ) between the pipette and the cell membrane. In most of the experiments, a high-resistance gigaohm-seal was first established between the recording pipette (containing the internal solution described below) and the cell membrane, and then by gentle application of brief pulses of negative pressure through the recording pipette, the membrane under the pipette tip was broken, thereby achieving whole-cell configuration.

Whole-cell voltage- and current-clamp recordings were performed by using 3-5 M $\Omega$ borosilicate glass pipettes pulled either with a PP-83 vertical puller (Narishige) or with a P-97 Flaming/Brown micropipette puller (Sutter Instruments). In some experiments, glass micropipettes were filled with an intracellular solution that contained the following (in $\mathrm{mm}): 150$ cesium methane-sulfonate $\left(\mathrm{CH}_{3} \mathrm{O}_{3} \mathrm{SCs}\right), 1 \mathrm{MgCl}_{2}, 10 \mathrm{HEPES}$, 0.5 EGTA, $2 \mathrm{Mg}$-ATP, $0.4 \mathrm{Na}_{2}$-GTP, and $10 \mathrm{Na}_{2}$-phosphocreatine, $\mathrm{pH}$ 7.3 , with $\mathrm{CsOH}$. For current-clamp experiments, we used a pipette solution containing (in mM) 120 potassium methyl sulfate $\left(\mathrm{KCH}_{3} \mathrm{SO}_{4}\right), 1$ $\mathrm{MgCl}_{2}, 10$ HEPES, 0.5 EGTA, $2 \mathrm{Mg}$-ATP, $0.4 \mathrm{Na}_{2}$-GTP, and $10 \mathrm{Na}_{2}-$ phosphocreatine, $\mathrm{pH} 7.3$, with $\mathrm{KOH}$. Slow and fast capacitive components were automatically compensated for. Access resistance was monitored throughout the experiments, and only those cells with stable access resistance (changes $<15 \%$ ) were used for analysis. The recordings were performed with an EPC9 amplifier (HEKA) and were controlled with Pulse software (HEKA). For all the whole-cell current-clamp experiments presented in Figures 1-3, liquid junction potentials were theoretically determined by using the generalized Henderson equation as described by Barry and Lynch (1991) and by J. L. Kenyon (University of Nevada Medical School, Reno, NV) at www.medicine.nevada.edu/ physio/docs/revised_primer_on_junction_potentials_3e.pdf and corrected accordingly in Results and also in the figures. For the voltageclamp experiments presented in Figure 7, we tried to mimic the conditions and values used by Ma et al. (2007). Because their values were not corrected for the liquid junction potential, we similarly did not correct ours to facilitate the comparison.

Unless noted otherwise, the experiments were done in normal ACSF at $34 \pm 2{ }^{\circ} \mathrm{C}$, with bath-applied drugs. In initial experiments (see Fig. 2), we tested the actions of both hypocretin-1 and -2 on the activity of POMC neurons. We found no difference in the responses to $1 \mu \mathrm{M}$ hypocretin- 1 or -2 , and therefore, unless noted otherwise, $1 \mu \mathrm{M}$ hypocretin- 2 was used in all the other experiments. In the experiment in which hypocretin actions on synaptic activity were tested, we used our Cs-based internal solution only (see above). EPSCs were studied at -60 or $-70 \mathrm{mV}$ holding potentials, with $20 \mu \mathrm{M}$ picrotoxin (or $30 \mu \mathrm{M}$ bicuculline in a few cases) in the bath to block $\mathrm{GABA}_{\mathrm{A}}$ receptor-mediated inhibitory transmission (see Fig. 4). Spontaneous GABAergic currents were, in turn, studied at 0 or $+10 \mathrm{mV}$ holding potentials, after blocking ionotropic glutamate receptors with a mix of $10 \mu \mathrm{M}$ 6-cyano-7-nitroquinoxaline2,3-dione (CNQX) and $50 \mu \mathrm{M}$ DL-2-amino-5-phosphonopentanoic acid (AP-5; see Fig. 5). In a few experiments (see Fig. $6 \mathrm{~B}$ ), the properties of hypocretin-induced current were studied using voltage ramps. These protocols consisted of relatively slow $(800 \mathrm{~ms})$ voltage ramps from -120 to 10 or $20 \mathrm{mV}$. Typically, these experiments were done with our Csbased internal solution, tetrodotoxin (TTX; $0.5 \mu \mathrm{M}$ ), and glutamate/ GABA synaptic blockers. In one set of experiments, we tested whether hypocretin can modulate whole-cell potassium currents. The cells were held at $-70 \mathrm{mV}$, and 5-10 depolarizing step pulses were applied through the recording pipette ( $5 \mathrm{mV}$ each, $200-400 \mathrm{~ms}, 3-5 \mathrm{~s}$ intervals). The effects of hypocretin were evaluated on both the peak and sustained component of the response. In these experiments, we used the K-based internal solution in voltage-clamp configuration after blocking voltagegated sodium channels and glutamate/GABA transmission.

Identification of neuroendocrine arcuate cells. The neuroendocrine nature of recorded arcuate cells [either in hypothalamic slices derived from wild-type mice (see Fig. 1) or from POMC-GFP transgenic mice (see Fig. $2 A, B)$ ] was established by two independent approaches. In some experiments, either a theta glass electrode (World Precision Instruments) or a custom stainless steel, Teflon-coated bipolar stimulating electrode was positioned in the ME to antidromically stimulate the axons of neuroendocrine arcuate cells. After single-shock electrical stimulation (usually lower than $100 \mathrm{uA}$ ), all or no antidromic spikes (latencies $\sim 1 \mathrm{~ms}$; range, $\approx 0.6-1.7 \mathrm{~ms}$ ) were readily detected in the soma via whole-cell currentclamp recordings. In other experiments (see Fig. $2 C, D$ ), POMC neuroendocrine cells were identified through fluorescent light in slices from mice that had received intravenous injections of $2 \%$ Evans blue $(100 \mu l)$ in the tail vein. By using multiple excitation filters, GFP and Evans blue coexpressing cells were identified and approached using DIC. For histological reconstruction of neuroendocrine projecting cells, some animals were perfused with $4 \%$ paraformaldehyde, postfixed overnight in the same solution, and dehydrated in high-sucrose-containing solutions (15-30\%) for 24-48 h. Hypothalamic sections $(20 \mu \mathrm{m})$ were cryostat cut, mounted, and observed in a fluorescence microscope. A Spot digital camera (Diagnostic Instruments) was used to produce photomicrographs. Contrast and brightness were adjusted with Photoshop 7.0 (Adobe Systems).

Data analysis and reagents. Data analysis was performed with PulseFit 8.54 (HEKA), Axograph 4.7 (Molecular Devices), and Igor Pro 4.07 (Wavemetrics) software. Spontaneous synaptic currents were detected using Axograph. Briefly, the detection was performed by comparison of the spontaneous events with a simulated template based on a double exponential function in which the time course (rise and decay) of a typical synaptic current was used. The template function was moved 
A

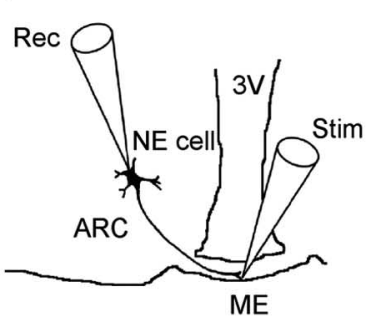

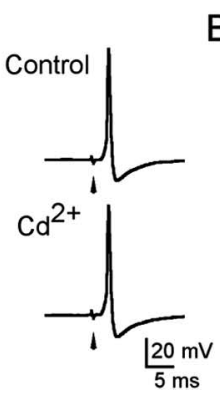

B

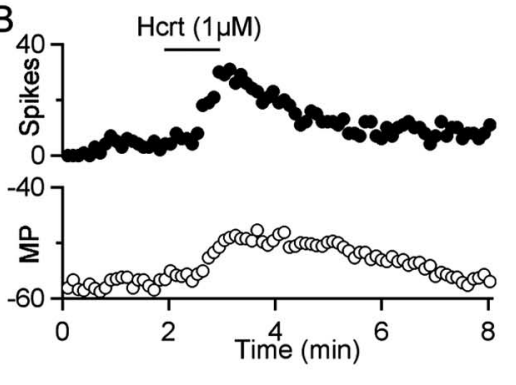

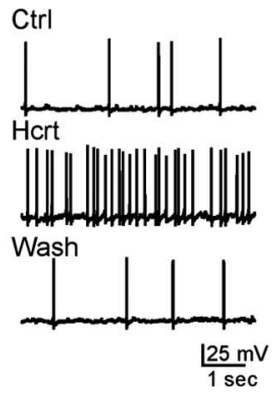

C

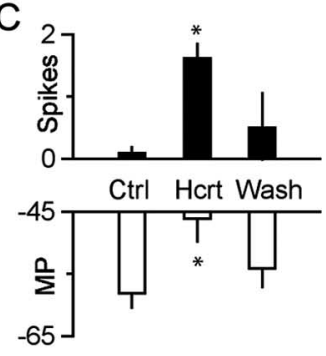

Figure 1. Neuroendocrine arcuate cells are activated by hypocretin. $\boldsymbol{A}$, Left, Schematic of experimental configuration. Arcuate nucleus neurons were recorded in whole-cell mode, whereas ME axons were antidromically activated with an extracellular electrode. Right, Sodium spikes in a representative neuron triggered by ME stimulation in control conditions (top) and in the presence of cadmium (bottom) to block conventional calcium-dependent transmitter release. Arrowheads show the timing of axonal stimulation. ARC, Arcuate nucleus; NE, neuroendocrine; $3 \mathrm{~V}$, third ventricle; Rec, recording electrode; Stim, stimulating electrode. $\boldsymbol{B}$, Left, A representative experiment is shown in which hypocretin increased spike frequency (per $6 \mathrm{~s}$ ) in a physiologically identified neuroendocrine cell (top). The changes in spike frequency triggered by hypocretin were accompanied by membrane depolarization as shown for the same neuron (bottom). Right, Traces of control, hypocretin, and washout conditions from the same experiment. C, A summary is shown for averaged hypocretin actions on firing rate (top; in Hz) and membrane potential (bottom) of arcuateneuroendocrine neurons. Error bars indicate SEM. Hcrt, Hypocretin; Ctrl, control; MP, membrane potential (in mV). Statistically signifcant ( $p<0.05)$ compared to control condition.

along the recorded trace, and individual events were compared with the template.

Data in Results are expressed as mean \pm SEM. Statistical analyses were performed on all POMC cells recorded for one particular experimental condition. We used one-way ANOVA followed by a Bonferroni post hoc procedure for between-group comparison (i.e., control, treatment, washout). A value of $p<0.05$ was considered statistically significant and is indicated by an asterisk in the figures. Most drugs were prepared as a 1000-fold stock solution. AP-5, CNQX, and bicuculline methiodide (BIC) were purchased from Sigma, and TTX was obtained from Alomone Labs. Hypocretin-1 and -2 were purchased from Phoenix Pharmaceuticals.

\section{Results}

Neuroendocrine arcuate neurons are excited by hypocretin peptides

Several studies have shown that hypocretin plays an important neuroendocrine role (Ida et al., 2000; Jászberényi et al., 2000; Al-Barzanji et al., 2001; Russell et al., 2001; Ferguson and Samson, 2003; Sakamoto et al., 2004; Spinazzi et al., 2006), but the cellular mechanisms underlying this are not well understood. To gain insight into the mechanisms that may account for hypocretin neuroendocrine actions, we explored whether hypocretin can directly affect the activity of arcuate (ARC) cells that send their axons into the ME.

To identify neuroendocrine ARC cells, we placed a bipolar extracellular electrode in the ME, stimulated the axons of neuroendocrine cells, and recorded antidromic spikes in the cell body in whole-cell current-clamp configuration (Fig. 1A, left). Single-shock extracellular stimulation of the ME evoked all or no sodium action potentials in arcuate neurons (Fig. $1 A$, top right). A number of independent lines of evidence suggest that they are likely to represent antidromic spikes triggered by direct axonal activation. (1) Increasing the stimulus intensity generated all or no spikes with little passive membrane depolarization because of subthreshold potentials. (2) The addition of the nonselective calcium channel blocker cadmium chloride (100-200 $\mu \mathrm{M})$, which would attenuate synaptic events, did not affect the ability of $\mathrm{ME}$ electrical stimulation to evoke somatic sodium spikes (Fig. $1 A$, bottom right). This suggests that spikes were triggered by a mechanism independent of calcium entry into presynaptic terminals, consistent with antidromic spikes. (3) Sodium spikes evoked by stimulation of the ME are unlikely to reflect direct activation of arcuate neuron somata attributable to current spread from stimulating regions because a delay $(\sim 1 \mathrm{~ms})$ between stimulus artifact and rising phase of the action potentials was commonly observed (Fig. $1 A$, right, traces). In addition, we evoked these spikes in $\sim 25 \%$ of recorded cells only; if they were caused by direct activation of the cell body, such a response should have been observed in most of the recordings. (4) Bath application of ionotropic glutamate receptor antagonists $[\mathrm{AP}-5$ and NBQX $(2,3-$ dioxo-6-nitro-1,2,3,4-tetrahydrobenzo[f] quinoxaline-7-sulfonoamide)] did not significantly affect the generation of spikes after ME stimulation but completely abolished action potentials evoked by extracellular stimulation ( $n=5$; data not shown) within the arcuate nucleus, suggesting that evoked spikes were not caused by activation of axon collaterals that might send their axons back into the arcuate nucleus.

Hypocretin strongly increased the firing rate and greatly depolarized most of the ME-projecting ARC cells (Fig. 1B). Hypocretin depolarized these responsive cells from $-58.4 \pm 2.4$ to $-46.3 \pm 3.7 \mathrm{mV}$ and significantly increased their firing $>10$-fold compared with control values (Fig. $1 C)(n=4$; $p<0.05)$. However, hypocretin did not excite all neurons tested. In two of six recorded neurons, hypocretin had no detectable effect on the activity of ARC-ME-projecting cells. This apparent lack of hypocretin sensitivity in some ARC-ME innervating cells could be attributable to a lack of hypocretin receptors on subsets of neurons in the arcuate nucleus, a region that contains cells with numerous phenotypic identities. Neurons in the arcuate can be segregated into chemically distinct cell populations, each with its own neurotransmitter/neuropeptide response profile. A particularly interesting cell type in the arcuate nucleus synthesizes POMC. Similar to hypocretin, peptides secreted by these cells, including $\alpha-\mathrm{MSH}$ and CART, have robust neuroendocrine effects (Conover et al., 1993; Contijoch et al., 1993; Prasad et al., 1993; Larsen et al., 2003). We therefore examined the effect of hypocretin peptides on the activity of identified neuroendocrine POMC-producing cells in the sections below.

\section{Hypocretin increases the activity of neuroendocrine POMC cells}

POMC neurons in the arcuate nucleus were identified by selective GFP expression in transgenic mice (Cowley et al., 2001; Batterham et al., 2002; Heisler et al., 2006; Münzberg et al., 2007) (Fig. 2 ). In some experiments (Fig. $2 A, B$ ), the neuroendocrine nature of these cells was determined by the presence of antidromic spikes triggered by extracellular stimulation of the $\mathrm{ME}$ as described 


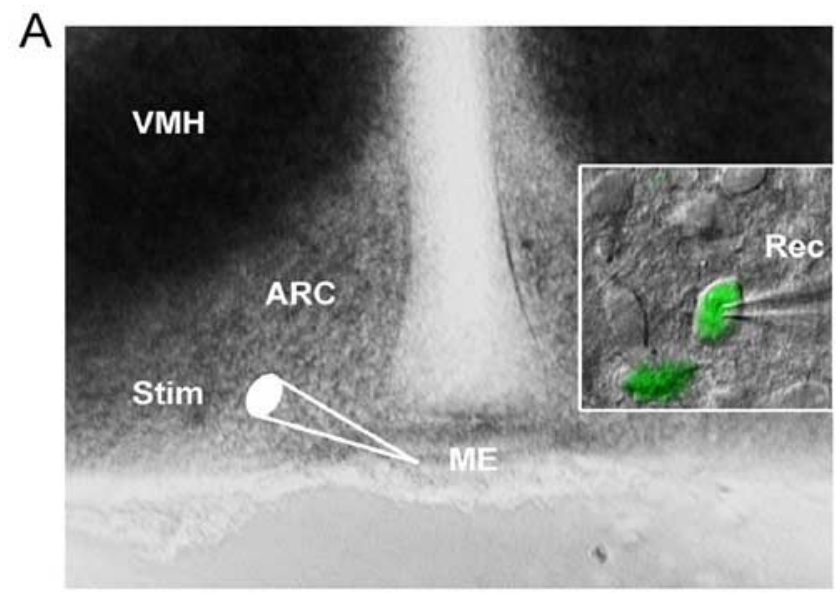

B

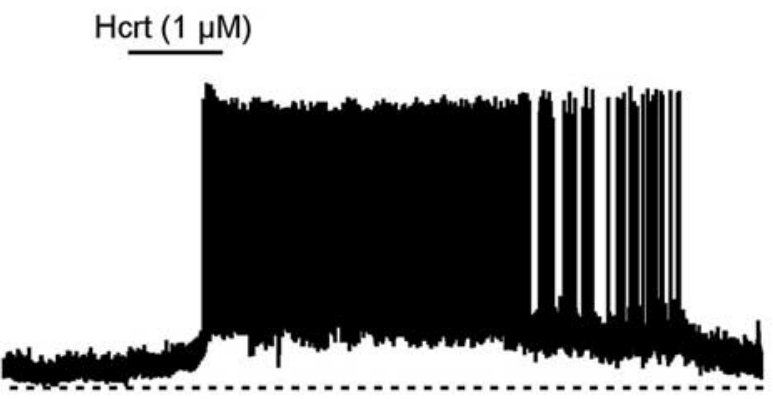

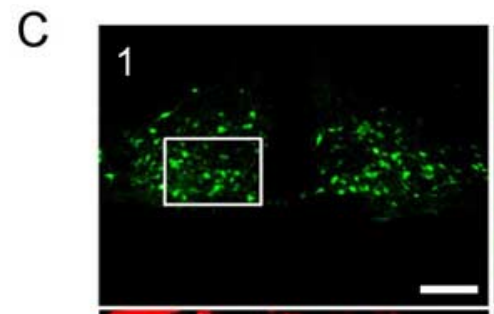
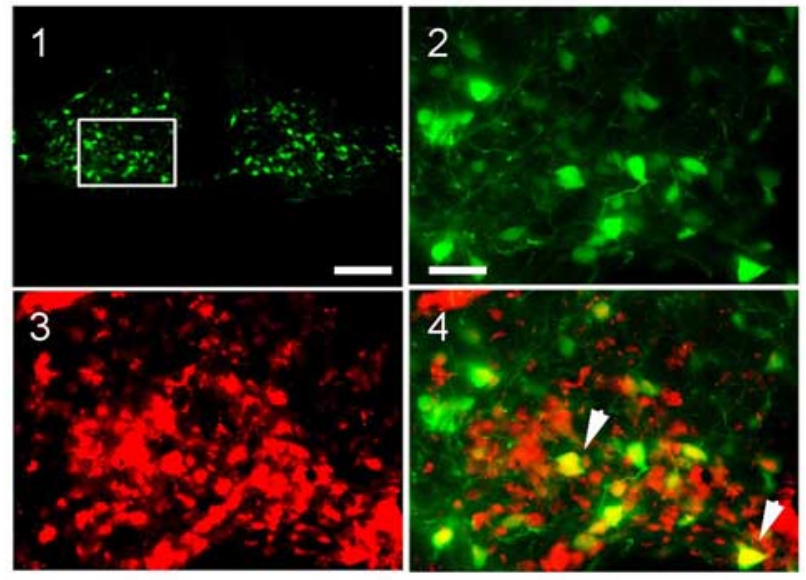

D

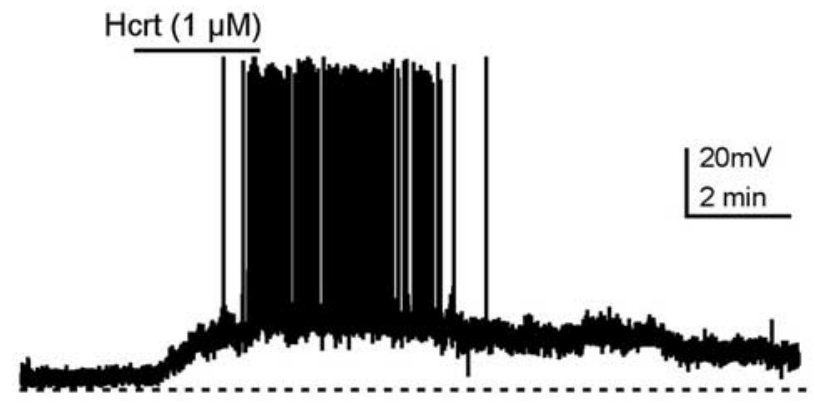

Figure 2. Hypocretin excites neuroendocrine POMC cells. A, Low-magnification DIC picture showing the mediobasal hypothalamus, including the arcuate nucleus. In the inset, a montage of a GFP-expressing POMC cell and its corresponding DIC image are shown (the recording pipette is also evident). The stimulus electrode used to determine the neuroendocrine nature of this representative POMC neuron is schematically shown in white. ARC, Arcuate nucleus; Rec, recording electrode; Stim, stimulating electrode; VMH, ventromedial nucleus. $\boldsymbol{B}$, Excitatory actions of hypocretin on the activity of the same physiologically identified neuroendocrine POMC cell shown in $\boldsymbol{A}$. $\boldsymbol{C}$, Histological reconstruction of a representative experiment in which a fluorescent dye was injected intravenously $3 \mathrm{~d}$ before sectioning. The low-magnification picture on the top left corner (1) shows GFP expression in a hypothalamic section from a POMC transgenic mouse. Highermagnification pictures from the region indicated by the white box (1) are shown for GFP expression (2), Evans blue fluorescence (red; 3), or both, shown by the yellow neurons (4). Some P0MC cells that also contain Evans blue are highlighted by the white arrowheads (4). Scale bars: 1, $100 \mu \mathrm{m} ; 2,20 \mu \mathrm{m}$. D, Hypocretin-mediated excitation in a representative neuroendocrine P0MC cell identified by intravenous Evans blue injection. Hcrt, Hypocretin.

above. Once an ME-projecting POMC cell was identified, the effect of hypocretin was determined in current-clamp mode (Fig. $2 B$ ). As shown for a representative experiment, hypocretin not only increased the firing of POMC cells but also robustly depolarized them. On average, hypocretin increased the spike frequency of physiologically identified POMC neuroendocrine cells by $320 \pm 48 \%$ compared with control $(n=4 ; p<0.05)$.

In other experiments, we used an alternative approach to identify neuroendocrine POMC cells (Fig. 2C,D) that is based on the fact that the ME has a weak blood-brain barrier. Fluorescent dyes injected into the bloodstream can be taken up by axon terminals innervating the ME and transported back into their cell bodies. Thus, injected dyes in the POMC transgenic mice bloodstream allowed us to readily identify ME-projecting POMC neurons in hypothalamic slices using fluorescent microscopy. We injected fluorescent dye (Evans blue, 2\%, $100 \mu \mathrm{l}$ ) intravenously in 15 POMC transgenic mice, and, after $1-4 \mathrm{~d}$, brain sections from those animals were cut for physiological experiments as well as for histological reconstruction. A representative experiment in which fixed brain sections were observed under the fluorescent microscope is shown in Figure 2C. In a typical arcuate section, several GFP-expressing neurons also contained Evans blue fluorescence, consistent with their neuroendocrine nature (Fig. 2C4, arrowheads). Other cells were labeled by the dye but showed no GFP expression. Brain slices containing the hypothalamus from Evans blue intravenous-injected POMC-GFP animals were also used for electrophysiological experiments. Doubly labeled ARC cells (ME-projecting POMC neurons) were identified with fluorescent microscopy and were approached and patch clamped under DIC. Hypocretin strongly depolarized doubly labeled neuroendocrine POMC neurons and increased their spiking activity. A representative example of these hypocretin excitatory actions is shown in Figure 2D. We repeated this experiment in eight cells from six different animals. In three of these cells, we bath applied hypocretin-1, whereas in the remaining five cells, we used hypocretin-2 peptide. We found no significant difference between these groups and therefore pooled all these data together. Unless noted otherwise, hypocretin-2 was used in the rest of this study. Overall, hypocretin application resulted in a significant $275 \pm 36 \%$ increase in the spike frequency of these cells. Thus, hypocretin greatly increases the activity of neuroendocrine POMC cells.

\section{Lack of inhibitory responses to hypocretin}

Our data show that neuroendocrine POMC cells are robustly activated by hypocretin. In contrast to this result, a recent study (Ma et al., 2007) suggested that hypocretin inhibited arcuate POMC cells, although the neuroendocrine nature of these cells was not determined. One possible explanation for these two types of responses is that there is heterogeneity in hypocretin sensitivity within POMC cells so that this peptide can excite the cells innervating the $\mathrm{ME}$ while inhibiting those that send their axons to 
A
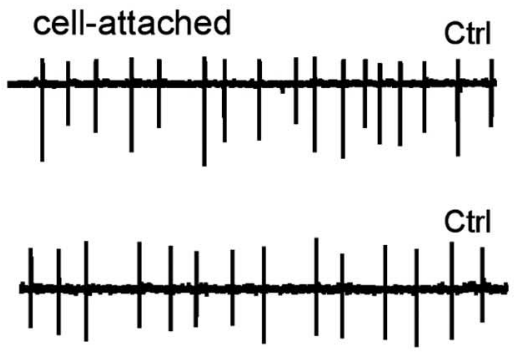

C
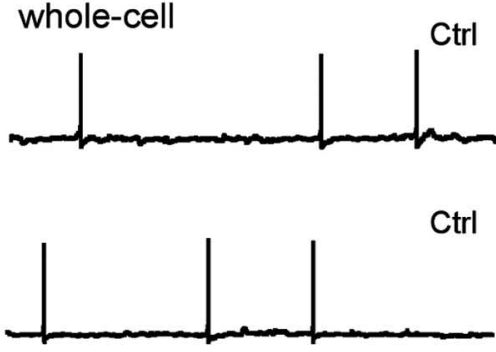

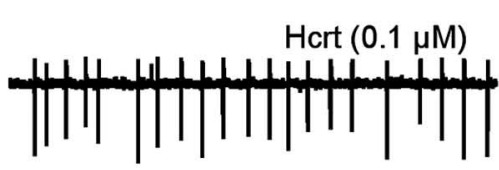

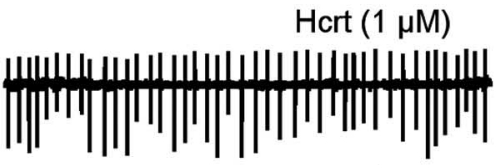

$30 \mathrm{pA}$
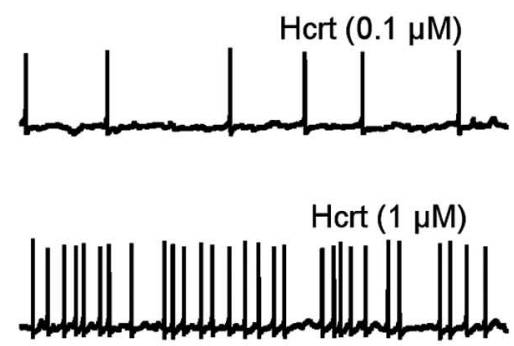

$20 \mathrm{mV}$
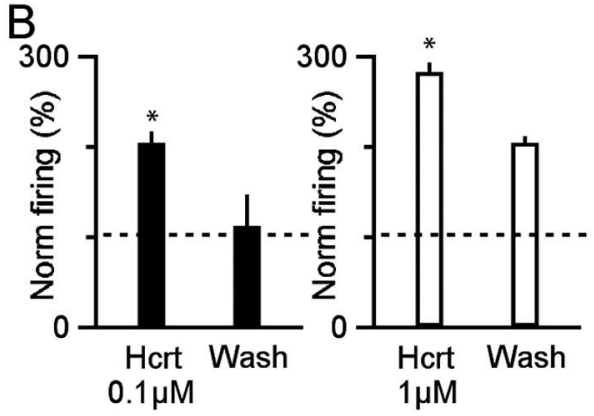

$\mathrm{D}$
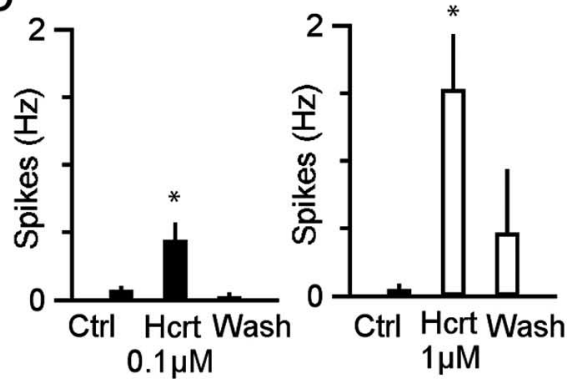

Figure 3. Both cell-attached and whole-cell recordings failed to detect hypocretin-mediated inhibition of POMC firing activity. $A$, Extracellular recordings in control (left) and hypocretin (right) conditions for doses of $0.1 \mu \mathrm{m}$ (top) and $1 \mu \mathrm{m}$ (bottom), respectively, in two typical cells. B, Averaged effects of low (left) and high (right) doses of hypocretin on POMC spiking studied in cell-attached configuration. $\boldsymbol{C}$, Whole-cell recording from two representative POMC neurons in control conditions (left) and in the presence of low (top right) or high (bottom right) doses of hypocretin. $\boldsymbol{D}$, Summary displaying the dose-dependent actions of hypocretin on POMC firing detected by whole-cell recording. Hcrt, Hypocretin; Ctrl, control. ${ }^{*} p<0.05$.

either the medial or lateral hypothalamus. In such a scenario, it would be predicted that both excitatory and inhibitory responses to hypocretin would be found when a high number POMC cells, projecting their axons to unknown targets, were recorded.

We tested this possibility by recording the hypocretin responses of 46 POMC neurons, in which their target (i.e., whether they send their axons to the ME, other hypothalamic areas, or both) was not determined (Fig. 3). In 18 of these cells, we performed cell-attached recordings, which allowed us to monitor the effects of hypocretin on firing rate without perturbing the cell or the intracellular ion milieu (Fig. 3A). Although some recorded cells showed relatively small responses to low doses of hypocretin $(0.1 \mu \mathrm{M})$, doses of $1 \mu \mathrm{M}$ hypocretin significantly increased spike frequency of the same cells. The increase in spike frequency for $0.1 \mu \mathrm{M}(n=9)$ was more than twofold, whereas for $1 \mu \mathrm{M}(n=14)$ the firing rate was increased to $282.6 \pm 10.7 \%$ of control levels (Fig. $3 B)(p<0.05)$. We also performed whole-cell patch-clamp experiments to determine whether hypocretin activation of POMC cells was accompanied by changes in membrane potential. Indeed, we observed that hypocretin not only greatly increased POMC spike frequency (from $0.08 \pm 0.02$ to $0.45 \pm 0.12$ $\mathrm{Hz}$ for $0.1 \mu \mathrm{M}$; from $0.06 \pm 0.04$ to $1.5 \pm 0.4 \mathrm{~Hz}$ for $1 \mu \mathrm{M}$ ) (Fig. $3 C, D)(p<0.05)$ but also significantly depolarized these cells. Hypocretin $(1 \mu \mathrm{M})$ depolarized the cells by a mean of $\sim 18 \mathrm{mV}$ (from $-59.9 \pm 1.2$ to $-41.1 \pm 6.2 \mathrm{mV} ; n=11$ ), whereas $0.1 \mu \mathrm{M}$ concentrations depolarized the cells by $\sim 7 \mathrm{mV}$ (from $-62.3 \pm$ 3.7 to $-54.3 \pm 4.2 \mathrm{mV} ; n=12$ ). Thus, in contrast to previously published results, under our experimental conditions, we failed to detect any inhibitory action of hypocretin on POMC spike frequency and consistently found strong excitatory actions.

\section{Presynaptic hypocretin effects and POMC spiking activity}

The activation of POMC cells by hypocretin can be explained by several mechanisms. One is that it can affect synaptic inputs to
POMC cells and thereby regulate activity. To gain insight into this, we first directly evaluated whether hypocretin can affect either excitatory or inhibitory synaptic transmission by measuring its effects on spontaneous excitatory and inhibitory synaptic currents, respectively. EPSCs, measured in the presence of picrotoxin $(20 \mu \mathrm{M})$ in the bath to block GABA-mediated synaptic activity, were studied before and after hypocretin application. Overall, in 21 cells, the frequency of EPSCs was reversibly increased from $7.2 \pm 1.7$ to $16.8 \pm 2.3 \mathrm{~Hz}$ after hypocretin application. Traces from a representative experiment as well as a summary of the population data are shown in Figure $4, A$ and $B$. In addition, we measured the effect of hypocretin on miniature EPSCs (mEPSCs) recorded in the presence of TTX (Fig. $4 C-F$ ). The amplitude of mEPSCs was not significantly altered when the cumulative distribution of mEPSCs for individual experiments was studied (Fig. 4C,D) or when the mEPSC amplitude was averaged across the population of recorded cells (Fig. $4 E$ ) (control, $42.2 \pm$ 6.2 ; hypocretin, $30.9 \pm 6.6 \mathrm{pA}$; wash, $37.3 \pm 4.6 \mathrm{pA} ; n=18)$. In parallel, in the same set of experiments, we measured the effect of hypocretin on mEPSC frequency and found that it was significantly increased from $6.9 \pm 0.6$ to $10.3 \pm 0.8 \mathrm{~Hz}$ as shown in Figure $4 F(n=18)$. This effect was reversible, and the frequency of mEPSCs returned to $8.1 \pm 0.9 \mathrm{~Hz}$ after peptide washout. These results suggest that hypocretin peptide can affect the activity of POMC cells by activating its receptors localized in glutamatergic axons, which would ultimately enhance glutamate release onto postsynaptic structures.

Alternatively, the changes in glutamatergic synaptic activity observed in POMC cells after hypocretin application might be explained by the release of a postsynaptic retrograde messenger, which could diffuse to presynaptic axons to modulate transmitter release. Hypocretin can raise intracellular calcium in hypothalamic neurons (van den Pol et al., 1998). Therefore, a possibility exists that calcium might initiate release of retrograde messengers 
that could presynaptically modulate synaptic inputs (i.e., through activation of either vanilloid or cannabinoid receptors) (Derbenev et al., 2006). We investigated this possibility by loading the postsynaptic cell with the calcium chelator BAPTA (20 $\mathrm{mm}$ ) (Beierlein and Regehr, 2006). If changes in synaptic activity evoked by hypocretin were attributable to the calcium-dependent release of a retrograde messenger, its effect on EPSCs should be blocked when BAPTA is loaded in the postsynaptic cell. However, we found that even after preventing postsynaptic calcium rises with BAPTA, there was still an increase in glutamatergic synaptic activity that was not significantly different than under control conditions (Fig. 4G) (control, $6.9 \pm 0.5 \mathrm{~Hz}$; hypocretin, $13.9 \pm 1.2$ $\mathrm{Hz}$; wash, $7.6 \pm 0.9 \mathrm{~Hz} ; n=8)$. Together, our results suggest that hypocretin actions on glutamate release are more likely caused by the activation of its presynaptic receptors and rule out a major contribution of retrograde messengers released in a calcium-dependent manner from POMC cells activated by hypocretin.

We also examined whether hypocretin can regulate the release of GABA onto arcuate POMC neurons by measuring its effect on spontaneous GABAergic currents (with ionotropic glutamate blockers in the bath; see Materials and Methods). We found that hypocretin significantly increased IPSC frequency from $6.9 \pm 1.1$ to $11.5 \pm 1.4 \mathrm{~Hz}$ (Figure $5 A, B)(n=9)$, a result consistent with previous observations (Ma et al., 2007). In addition, we noticed that hypocretin also increased the amplitude of GABAergic currents recorded in POMC cells from 69.9 \pm 2.1 to $89.4 \pm 1.2 \mathrm{pA}$ (Fig. 5C,D) $(n=9)$. Analysis of miniature inhibitory currents in six experiments showed no significant hypocretin effect on miniature IPSC (mIPSC) frequency (Fig. $5 E)(n=5$; control, $5.6 \pm 1.9 \mathrm{~Hz}$; hypocretin, $5.4 \pm 1.8 \mathrm{~Hz}$; wash, $4.9 \pm 1.9$ ) or their amplitude (Fig. $5 F$ ) $(n=5 ; 41.2 \pm 12.1 \mathrm{pA}$; hypocretin, $37.4 \pm 10.4 \mathrm{~Hz}$; wash, $40.2 \pm$ $16.6 \mathrm{~Hz}$ ). Thus, in contrast to its actions on glutamatergic inputs, hypocretin effects on IPSCs are spike dependent and likely attributable to the activation of the cell body/dendrites of nearby GABAergic cells projecting their axons onto recorded POMC neurons.

Together, the results presented above show that hypocretin peptide can modulate both excitatory and inhibitory activity, raising the possibility that its effect on firing rate could be mediated by presynaptic actions on either glutamate or GABA release. We evaluated this in cell-attached mode when either glutamatergic (Fig. 6A1,B1) or GABAergic (Fig. 6A2,B2) transmission was blocked with selective antagonists (see Materials and Methods). If hypocretin-mediated POMC activation were dependent on presynaptic actions, blockade of synaptic inputs would be expected to eliminate such excitation. Pharmacological blockade of fast glutamatergic transmission did not prevent hypocretin excitation of POMC cells, as shown in a representative experiment in Figure $6 \mathrm{A1}$. A summary of the mean effects of hypocretin on
POMC spiking activity under these experimental conditions in six experiments is shown in Figure $6 B 1$ (control, $2.2 \pm 0.1 \mathrm{~Hz}$; hypocretin, $3.4 \pm 0.2 \mathrm{~Hz}$ ). In addition, when inhibitory transmission was eliminated by blocking ionotropic GABA receptors (Fig. $6 A 2, B 2)$, hypocretin could also significantly increase the firing rate of POMC neurons (from $1.6 \pm 0.1$ to $3.2 \pm 0.3 \mathrm{~Hz} ; n=5$ ). Even when both the inhibitory and excitatory inputs to POMC cells were pharmacologically blocked (Fig. 6A3,B3), hypocretin still enhanced the activity of these cells (from $0.6 \pm 0.2$ to $2.7 \pm$ $0.3 \mathrm{~Hz} ; n=5$ ), further substantiating the idea that although hypocretin can affect synaptic inputs to these hypothalamic neurons, these indirect actions do not appear to be necessary to increase spiking activity. These findings also suggested that hypocretin exerts direct postsynaptic actions on POMC cells, thereby increasing their firing rate.

\section{Direct postsynaptic actions of hypocretin on POMC cells}

Immunohistochemical and calcium imaging experiments have previously suggested that POMC cells express hypocretin receptors (Bäckberg et al., 2002; Muroya et al., 2003). We therefore tested whether hypocretin activation of these postsynaptic receptors could affect the membrane potential of POMC cells. To eliminate indirect hypocretin actions, we blocked both excitatory and inhibitory transmission with selective antagonists (see Materials and Methods) as well as network spike-dependent hypocretin actions with TTX. Under these conditions, bath application of 
Hypocretin potentiates GABAergic transmission in POMC neurons
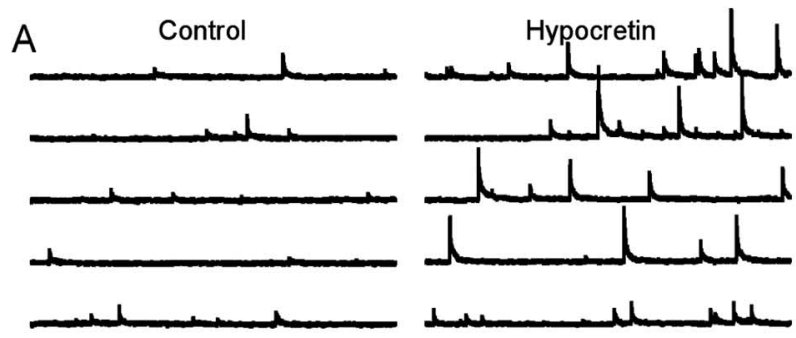

C

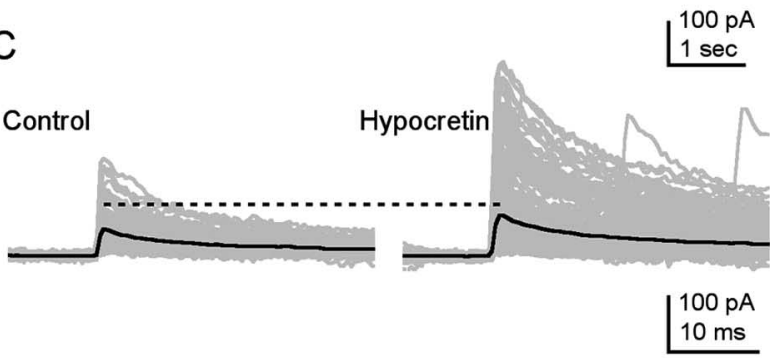

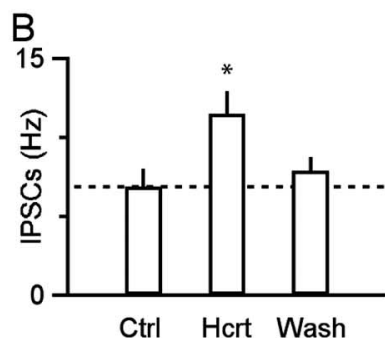

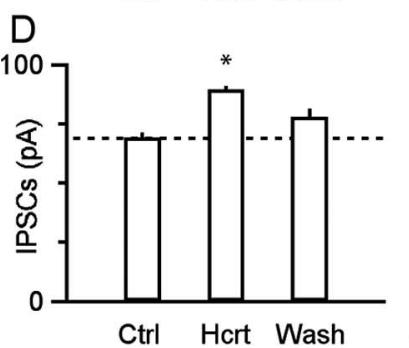

Hypocretin does not affect mIPSCs

E

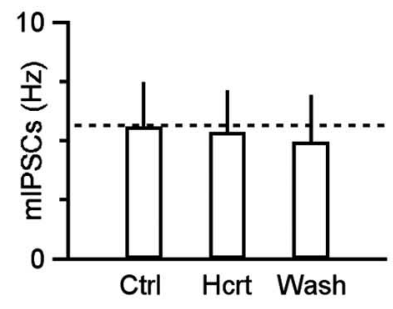

$\mathrm{F}$

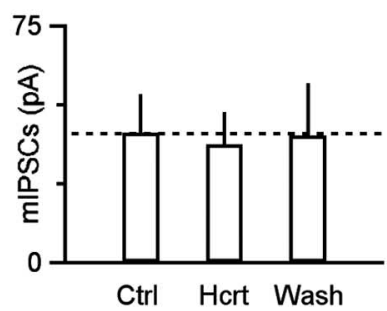

Figure 5. Spike-dependent regulation of GABA release onto POMC neurons by hypocretin. $A, B$, Traces from a representative experiment $(\boldsymbol{A})$ and summary of nine cells $(\boldsymbol{B})$ showing IPSC frequency before and during hypocretin application. C, IPSC waveforms detected in the same experiment presented in $A$. Individual events are shown in gray, and the mean is shown in black. Note the increased IPSC amplitude in the presence of hypocretin. $\boldsymbol{D}$, Averaged effect of hypocretin on IPSC amplitude $(n=9) . \boldsymbol{E}, \boldsymbol{F}$, Lack of hypocretin effect is shown either for mIPSC frequency $(\boldsymbol{E})$ or amplitude $(\boldsymbol{F})$ in six POMC neurons. Hcrt, Hypocretin; Ctrl, control. * $p<0.05$.

A
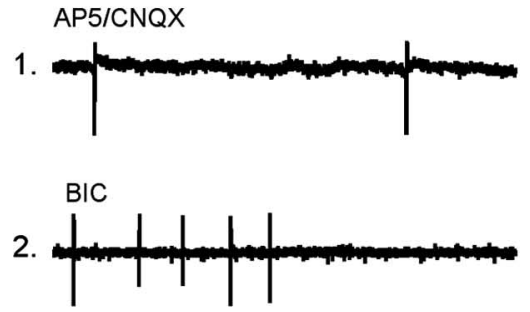

$\mathrm{AP} 5 / \mathrm{CNQX}+\mathrm{BIC}$

3.

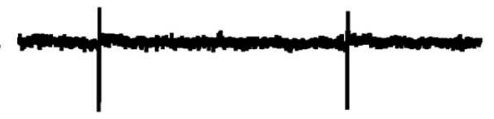

$\operatorname{Hcrt}(1 \mu \mathrm{M})$
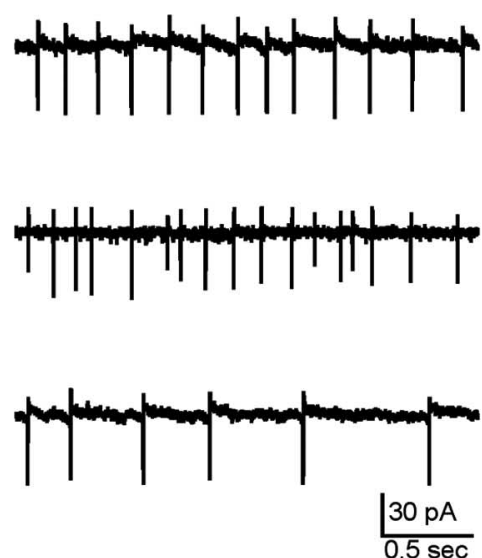

$\begin{array}{cc}\text { B } & 5 \\ & \frac{1}{1} \\ 0 \\ 1 . \\ 0 \\ 0 \\ 0 \\ 0 \\ 0\end{array}$

2.

3.

Figure 6. Hypocretin excitatory actions are independent of synaptic input. $A$, Cell-attached recordings in three representative POMC cells in control (left) and hypocretin (right) conditions after pharmacological blockade of their glutamatergic (1), GABAergic (2), or both glutamatergic/GABAergic (3) synaptic inputs. B, The summary of the population data for all three conditions is displayed. Hert, Hypocretin; Ctrl, control; AP, action potential. ${ }^{*} p<0.05$.

hypocretin resulted in a substantial and significant $17.9 \pm 4.5 \mathrm{mV}$ depolarization in POMC cells. A summary of population responses is presented in Figure 7C. Recovery was achieved, between 5 and 15 min after peptide washout (control, $-60.9 \pm 1.2$ $\mathrm{mV}$; hypocretin, $-43.0 \pm 7.2 \mathrm{mV}$; washout, $-55.1 \pm 1.6 \mathrm{mV} ; n=$ $8 ; p<0.05)$.

Previous studies have shown that external glucose concentration can control the activity of POMC neurons (Parton et al., 2007), suggesting that glucose levels in the bath may affect the ability of these cells to respond to modulators, including hypocretin. We thus tested the action of hypocretin on POMC membrane potential in the presence of lower external glucose concentrations (5 and $2 \mathrm{~mm}$ ). We found that with either 5 or $2 \mathrm{mM}$ external glucose, hypocretin still evoked a robust POMC depolarization of $12.1 \pm 4.1 \mathrm{~m} \mathrm{~V}(n=3)$ and $6.1 \pm 1.8 \mathrm{mV}(n=5)$, respectively. Thus, direct activation of postsynaptic hypocretin receptors is sufficient to cause membrane depolarization even under low external glucose concentration. These direct postsynaptic actions of hypocretin likely contribute to its excitatory action on POMC cell spiking activity.

We next attempted to determine the postsynaptic mechanism by which hypocretin depolarized POMC cells. While performing whole-cell voltage-clamp experiments with synaptic blockers and TTX in the bath, we noticed that, at negative potentials ( -60 to $-70 \mathrm{mV}$ ), hypocretin induced a slow inward current in recorded cells. Recordings from a representative experiment are shown in Figure $7 A$. In addition to these changes in the holding current, hypocretin increased the synaptic noise, represented by an increase in the thickness of the recorded current (Fig. 7A, right), further suggesting increases in channel activity.

To gain insight into the properties of the conductance activated by hypocretin in POMC soma/dendrites, we performed 

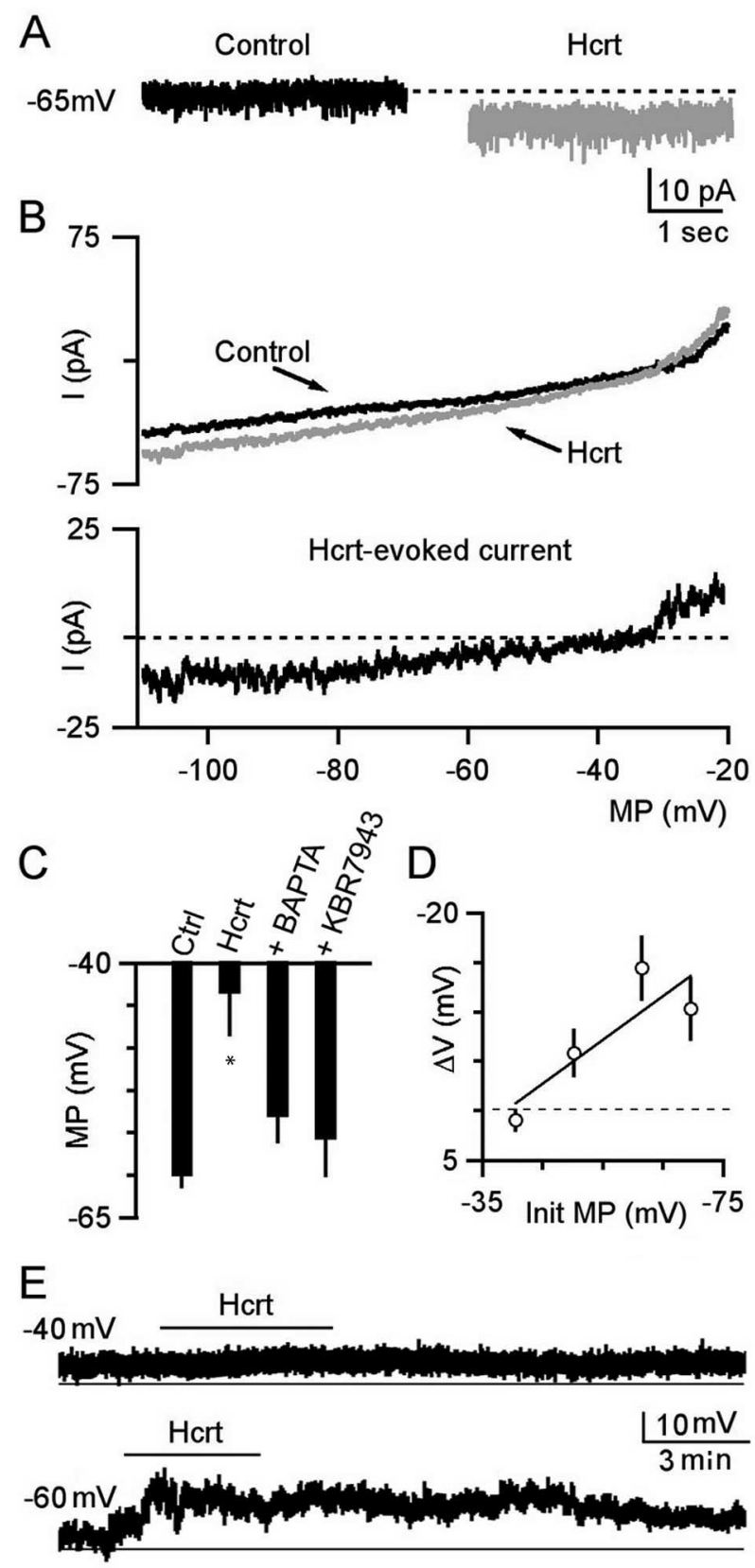

Figure 7. Mechanisms of postsynaptic hypocretin depolarization. $\boldsymbol{A}$, Whole-cell voltageclamp recording from a representative POMC neuron showing the effect of hypocretin on the holding potential and channel activity in the presence of TTX and blockers of glutamate and GABA transmission. $\boldsymbol{B}$, Top, Effect of hypocretin on current response recorded in voltage clamp after a slow voltage ramp from -110 to $-20 \mathrm{mV}$. Bottom, Net hypocretin-induced current obtained by subtracting control from hypocretin condition. C, Summary of current-clamp recordings displaying the actions of hypocretin on POMC membrane potential in control (Ctrl) conditions, or in the presence of BAPTA in the pipette solution, or KB-R7943 in the bath. ${ }^{*} p<$ 0.05. D, The impact of initial membrane potential on hypocretin-evoked POMC depolarization in 22 cells. These neurons were grouped ( $10 \mathrm{mV}$ bins) according to their initial membrane potential. Net depolarization $(\Delta V)$ was plotted against initial membrane potential (init MP), and a linear function was fitted (thin line; $Y=17.2+0.4 X$ ). $\boldsymbol{E}$, Effect of hypocretin on membrane potential in a representative POMC cell maintained either near $-40 \mathrm{mV}$ (top) or around -60 $\mathrm{mV}$ (see Materials and Methods). Hert, Hypocretin; MP, membrane potential.

voltage-ramp experiments (see Materials and Methods) in control conditions and in the presence of hypocretin in the bath. As displayed in Figure 7B, hypocretin induced an inward current at negative potentials that decreased in amplitude as the cells be- came more depolarized and reversed between -6 and $-43 \mathrm{mV}$ (mean reversal potential, $-38.5 \pm 5.6 \mathrm{mV}$ ). One possibility that may explain such a reversal potential is that hypocretin activates the sodium-calcium exchanger (NCX), as reported for GABAergic cells in the arcuate nucleus (Burdakov et al., 2003). Arcuate POMC neurons appear to synthesize and release GABA (Hentges et al., 2004), and therefore we tested whether activation of NCX might contribute to the observed POMC depolarization after hypocretin application (Fig. $7 C$ ). In the presence of the NCX inhibitor KB-R7943 (50-100 $\mu \mathrm{M})$ (Eriksson et al., 2001a; Burdakov et al., 2003) in the bath, hypocretin failed to significantly depolarize POMC cells. In addition, hypocretin also failed to robustly depolarize hypocretin neurons when BAPTA (10 mM) was included in the recording pipette, a result consistent with the involvement of NCX. Postsynaptic actions mediated by activation of the NCX, but not by ion channels, have been shown to be highly temperature dependent (Eriksson et al., 2001a). Therefore, determining whether hypocretin-mediated excitation of POMC cells is sensitive to changes in bath temperature would provide additional insight into the involvement of the NCX. We thus lowered the bath temperature in the recording chamber to $22 \pm 2{ }^{\circ} \mathrm{C}$ and evaluated the actions of hypocretin under this experimental condition. Hypocretin-mediated depolarization was then drastically reduced (from $17.9 \pm 7.2 \mathrm{mV}$ at $\sim 34^{\circ} \mathrm{C}$ to $4.4 \pm 1.5 \mathrm{mV}$ at $\sim 22^{\circ} \mathrm{C} ; n=8$ and $n=12$, respectively). This observation is consistent with the reported reduction in the depolarization mediated by activation of the NCX at low temperatures (Eriksson et al., 2001a). Thus, similar to GABA neurons in the arcuate nucleus (Burdakov et al., 2003), our results are consistent with an involvement of NCX in hypocretin-mediated depolarization of POMC cells.

Our voltage-ramp experiments suggest that POMC cells with relatively positive membrane potentials would show less pronounced depolarization in response to hypocretin. We therefore plotted the peak amplitude of the hypocretininduced depolarization as a function of the initial membrane potential in 22 POMC neurons. We found, as predicted by voltage-ramp experiments, that hypocretin was less effective in activating POMC neurons with more depolarized membrane potentials (Fig. 7D). A representative experiment is shown in Figure $7 E$ in which the actions of hypocretin are tested at two different membrane potentials in the same POMC cell. First, when the cell was maintained near $-40 \mathrm{mV}$ (by constant positive current injection through the recording pipette), hypocretin exerted little depolarizing action. Switching the membrane potential to around $-60 \mathrm{mV}$ (the normal resting membrane potential of this particular neuron) unmasked a hypocretin-mediated depolarization of $\sim 10 \mathrm{mV}$ in the same cell. Thus, these experiments reveal that direct excitatory actions of hypocretin are less apparent in more depolarized POMC cells. This result is also consistent with the lack of modulation of whole-cell potassium current by hypocretin, observed in six experiments $(n=6$; data not shown).

\section{Discussion}

Here, we studied the actions of hypocretin on the activity of identified POMC cells, including neuroendocrine POMC neurons. Hypocretin not only increased synaptic transmission in these cells but also dramatically increased their activity via direct stimulation of postsynaptic receptors. Thus, in contrast to previous findings (Ma et al., 2007), our results show direct robust excitatory actions of hypocretin on POMC neurons. These find- 
ings reveal a potential mechanism underlying neurondocrine regulation by hypocretin peptides.

\section{Mechanisms of hypocretin excitation of POMC neurons}

In contrast to previous suggestions that hypocretin inhibits POMC neurons (Ma et al., 2007), a major finding here is that hypocretin directly excites these cells, including those POMC cells that send their axons into the ME. Our result is very different from hypocretin actions described before in this hypothalamic neuron subtype. We find that hypocretin peptides strongly increase the firing rate and depolarize POMC cells, whereas the previous report (Ma et al., 2007) suggested that hypocretin decreased spike frequency and hyperpolarized the same neurons. What might contribute to this seeming discrepancy? Our results indicate that the experimental conditions used by Ma et al. (2007) may mask the direct postsynaptic activation of POMC cells by hypocretin. Here, we demonstrate a potent, reversible, concentration-dependent, excitatory action of hypocretin that persisted in the presence of TTX, and that is likely mediated by direct activation of the NCX. In contrast, the previous study (Ma et al., 2007) did not detect any direct activation of postsynaptic receptors in POMC cells, although early reports substantiate the presence of hypocretin receptors in these cells (Bäckberg et al., 2002; Muroya et al., 2003).

The function of ion exchangers is highly temperature sensitive, and recordings at relatively low temperatures, such as the $22-25^{\circ} \mathrm{C}$ used by $\mathrm{Ma}$ et al. (2007), may block cellular responses that are present at normal physiological temperatures. Eriksson et al. (2001a) reported a dramatic reduction in the depolarization mediated by activation of the NCX at temperatures lower than physiological. Our experiments show that when the bath temperature was lowered from $34^{\circ} \mathrm{C}$ to $22^{\circ} \mathrm{C}$, the actions of hypocretin on POMC membrane depolarization were reduced by almost $80 \%$. This observation reveals that direct hypocretin actions can be masked at nonphysiological temperatures and also provides one potential explanation for the discrepancy between our results and those published by Ma et al. (2007).

Second, we find that the most likely mechanism for hypocretin-mediated excitation is the activation of the NCX that reverses near $-38 \mathrm{mV}$. In the previous study by Ma et al. (2007), the resting membrane potential of recorded cells was approximately $-38 \mathrm{mV}$ (Fig. $1 D$ ), which is very close to the reversal potential found here for hypocretin-induced current. Thus, activation of this current by hypocretin in cells with a resting membrane potential near the reversal potential might mask its excitatory effect. In our experiments, the mean resting membrane potential was approximately $-60 \mathrm{mV}[20 \mathrm{mV}$ negative to that suggested by Ma et al. (2007), their Fig. 1], and under our physiological conditions, hypocretin evoked a large depolarization, sometimes $>20 \mathrm{mV}$; in contrast, when we artificially held the membrane potential near $-40 \mathrm{mV}$, hypocretin then evoked little or no depolarization and had little effect on the firing rate. To avoid concerns about the relative composition of the whole-cell pipette that might dialyze the normal cytoplasmic milieu, we also used cell-attached recording that leaves both the resting membrane potential and intracellular milieu unaltered and found that hypocretin was still very excitatory. Positive resting membrane potentials are unusual for healthy neurons; cells with such resting potentials are sometimes excluded from data analysis (Eriksson et al., 2001a,b). That neurons with relatively positive membrane potentials may not represent normal POMC neurons is also substantiated by the lack of recovery found in the majority of neurons after the "inhibition" evoked by hypocretin in the study by
Ma et al. (2007). In some of the neurons illustrated (Ma et al., 2007, their Fig. $3 A$, bottom traces), although no depolarization was noted, each of the traces in the presence of hypocretin showed more "noise," suggestive of channel opening.

\section{Functional implications of hypocretin excitation of POMC neurons}

In the anterior pituitary, a number of hormones [ACTH, prolactin (PRL), follicle-stimulating hormone, luteinizing hormone, etc.] are secreted from endocrine cells into the bloodstream. Pituitary hormone-producing cells are regulated by pituitary tropins released by hypothalamic axon terminals into blood vessels in the ME. These vessels carry the hypothalamic factors to the anterior pituitary gland where they bind to specific receptors on the surface of the endocrine cells.

Hypothalamic hypocretin cells (de Lecea et al., 1998) appear to play a significant role in controlling hormone release from the anterior pituitary. Central injections of hypocretin alter ACTH and PRL secretions (Ida et al., 2000; Jászberényi et al., 2000; AlBarzanji et al., 2001; Russell et al., 2001; Ferguson and Samson, 2003; Sakamoto et al., 2004; Spinazzi et al., 2006). These neuroendocrine actions could be mediated in part by activation of neuroendocrine neurons in the hypothalamus (Freeman et al., 2000; Ferguson and Samson, 2003). Along this line, hypocretincontaining axonal boutons have been observed near or synapsing with arcuate nucleus cells (Peyron et al., 1998; Horvath et al., 1999). These neurons also express pronounced levels of hypocretin receptors (Bäckberg et al., 2002; Muroya et al., 2003), further suggesting that arcuate neuroendocrine cells could be modulated by hypocretins. Here, we report that neuroendocrine POMC neurons, identified either by antidromic stimulation or after intravenous dye injections, are strongly activated by hypocretin peptides. Our results support the idea that POMC neurons may play a pivotal role in mediating hypocretin neuroendocrine actions. Hypocretin-producing cells probably do not directly control hormone secretions but participate in neuroendocrine regulation by selectively affecting the firing of POMC neurons that, in turn, can control pituitary function. Activation of POMC neurons by hypocretin would also tend to increase the release of POMC peptides and colocalized GABA (Hentges et al., 2004) on other arcuate neurons that could also modulate pituitary secretions.

In a current model of central control of feeding, POMC neurons are considered to provide an anorexigenic tone (Cowley et al., 2001). In an early description of hypocretin (Sakurai et al., 1998), the suggestion was made that hypocretin (orexin) promoted food intake, and if this were true, then hypocretinmediated inhibition of POMC neurons could be an explanation for that. However, in narcoleptic animals or humans lacking hypocretin or its receptors, the primary morphotype is one of a modest increase (not decrease) in body weight (Hara et al., 2001, 2005). This weight gain could in part be attributable to a reduced level of physical activity in narcoleptic subjects. An additional mechanism for the increase in body weight in narcolepsy, consistent with the results described here, is that when the hypocretinmediated excitatory tone on the POMC cells is reduced as hypocretin cells are lost in narcolepsy, then the POMC neurons may by less active, leading to a weight gain.

\section{References}

Al-Barzanji KA, Wilson S, Baker J, Jessop DS, Harbuz MS (2001) Central orexin-A activates the hypothalamic-pituitary-adrenal axis and stimulates hypothalamic corticotropin releasing factor and arginine vasopressin neurons in conscious rats. J Neuroendocrinol 13:421-424. 
Bäckberg M, Hervieu G, Wilson S, Meister B (2002) Orexin receptor-1 (OXR1) immunoreactivity in chemically identified neurons of the hypothalamus: focus on orexin targets involved in control of food and water intake. Eur J Neurosci 15:315-328.

Barry PH, Lynch JW (1991) Liquid junction potentials and small cell effects in patch-clamp analysis. J Membr Biol 121:101-117.

Batterham RL, Cowley MA, Small CJ, Herzog H, Cohen MA, Dakin CL, Wren AM, Brynes AE, Low MJ, Ghatei MA, Cone RD, Bloom SR (2002) Gut hormone PYY(3-36) physiologically inhibits food intake. Nature 418:650-654.

Beierlein M, Regehr WG (2006) Local interneurons regulate synaptic strength by retrograde release of endocannabinoids. J Neurosci 26:9935-9943.

Bingham MJ, Cai J, Deehan MR (2006) Eating, sleeping and rewarding: orexin receptors and their antagonists. Curr Opin Drug Discov Dev 9:551-559.

Burdakov D, Liss B, Ashcroft FM (2003) Orexin excites GABAergic neurons of the arcuate nucleus by activating the sodium-calcium exchanger. J Neurosci 23:4951-4957.

Chemelli RM, Willie JT, Sinton CM, Elmquist JK, Scammell T, Lee C, Richardson JA, Williams SC, Xiong Y, Kisanuki Y, Fitch TE, Nakazato M, Hammer RE, Saper CB, Yanagisawa M (1999) Narcolepsy in orexin knockout mice: molecular genetics of sleep regulation. Cell 98:437-451.

Conover CD, Kuljis RO, Rabii J, Advis JP (1993) Beta-endorphin regulation of luteinizing hormone-releasing hormone release at the median eminence in ewes: immunocytochemical and physiological evidence. Neuroendocrinology 57:1182-1195.

Contijoch AM, Malamed S, Sarkar DK, Advis JP (1993) Beta-endorphin regulation of LHRH release at the median eminence level: immunocytochemical and physiological evidence in hens. Neuroendocrinology 57:365-373.

Cowley MA, Smart JL, Rubinstein M, Cerdán MG, Diano S, Horvath TL, Cone RD, Low MJ (2001) Leptin activates anorexigenic POMC neurons through a neural network in the arcuate nucleus. Nature 411:480-484.

Date Y, Ueta Y, Yamashita H, Yamaguchi H, Matsukura S, Kangawa K, Sakurai T, Yanagisawa M, Nakazato M (1999) Orexins, orexigenic hypothalamic peptides, interact with autonomic, neuroendocrine and neuroregulatory systems. Proc Natl Acad Sci U S A 96:748-753.

de Lecea L, Kilduff TS, Peyron C, Gao X, Foye PE, Danielson PE, Fukuhara C, Battenberg EL, Gautvik VT, Bartlett FS 2nd, Frankel WN, van den Pol AN, Bloom FE, Gautvik KM, Sutcliffe JG (1998) The hypocretins: hypothalamus-specific peptides with neuroexcitatory activity. Proc Natl Acad Sci U S A 95:322-327.

Derbenev AV, Monroe MJ, Glatzer NR, Smith BN (2006) Vanilloidmediated heterosynaptic facilitation of inhibitory synaptic input to neurons of the rat dorsal motor nucleus of the vagus. J Neurosci 26:9666-9672.

Eriksson KS, Stevens DR, Haas HL (2001a) Serotonin excites tuberomammillary neurons by activation of $\mathrm{Na}(+) / \mathrm{Ca}(2+)$-exchange. Neuropharmacology 40:345-351.

Eriksson KS, Sergeeva O, Brown RE, Haas HL (2001b) Orexin/hypocretin excites the histaminergic neurons of the tuberomammillary nucleus. J Neurosci 21:9273-9279.

Ferguson AV, Samson WK (2003) The orexin/hypocretin system: a critical regulator of neuroendocrine and autonomic function. Front Neuroendocrinol 24:141-150.

Freeman ME, Kanyicska B, Lerant A, Nagy G (2000) Prolactin: structure, function, and regulation of secretion. Physiol Rev 80:1523-1631.

Guan JL, Saotome T, Wang QP, Funahashi H, Hori T, Tanaka S, Shioda S (2001) Orexinergic innervation of POMC-containing neurons in the rat arcuate nucleus. Neuroreport 12:547-551.

Hagan JJ, Leslie RA, Patel S, Evans ML, Wattam TA, Holmes S, Benham CD, Taylor SG, Routledge C, Hemmati P, Munton RP, Ashmeade TE, Shah AS, Hatcher JP, Hatcher PD, Jones DN, Smith MI, Piper DC, Hunter AJ, Porter RA, Upton N (1999) Orexin A activates locus coeruleus cell firing and increases arousal in the rat. Proc Natl Acad Sci USA 96:10911-10916.

Hara J, Beuckmann CT, Nambu T, Willie JT, Chemelli RM, Sinton CM, Sugiyama F, Yagami K, Goto K, Yanagisawa M, Sakurai T (2001) Genetic ablation of orexin neurons in mice results in narcolepsy, hypophagia, and obesity. Neuron 30:345-354.

Hara J, Yanagisawa M, Sakurai T (2005) Difference in obesity phenotype between orexin-knockout mice and orexin neuron-deficient mice with same genetic background and environmental conditions. Neurosci Lett 380:239-242.

Heisler LK, Jobst EE, Sutton GM, Zhou L, Borok E, Thornton-Jones Z, Liu HY, Zigman JM, Balthasar N, Kishi T, Lee CE, Aschkenasi CJ, Zhang CY, Yu J, Boss O, Mountjoy KG, Clifton PG, Lowell BB, Friedman JM, Horvath T, Butler AA, Elmquist JK, Cowley MA (2006) Serotonin reciprocally regulates melanocortin neurons to modulate food intake. Neuron 51:239-249.

Hentges ST, Nishiyama M, Overstreet LS, Stenzel-Poore M, Williams JT, Low MJ (2004) GABA release from proopiomelanocortin neurons. J Neurosci 24:1578-1583.

Hervieu GJ, Cluderay JE, Harrison DC, Roberts JC, Leslie RA (2001) Gene expression and protein distribution of the orexin-1 receptor in the rat brain and spinal cord. Neuroscience 103:777-797.

Horvath TL, Diano S, van den Pol AN (1999) Synaptic interaction between hypocretin (orexin) and neuropeptide $\mathrm{Y}$ cells in the rodent and primate hypothalamus: a novel circuit implicated in metabolic and endocrine regulations. J Neurosci 19:1072-1087.

Ida T, Nakahara K, Murakami T, Hanada R, Nakazato M, Murakami N (2000) Possible involvement of orexin in the stress reaction in rats. Biochem Biophys Res Commun 270:318-323.

Jászberényi M, Bujdosó E, Pataki I, Telegdy G (2000) Effects of orexins on the hypothalamic-pituitary-adrenal system. J Neuroendocrinol 12:1174-1178

Larsen PJ, Seier V, Fink-Jensen A, Holst JJ, Warberg J, Vrang N (2003) Cocaine- and amphetamine-regulated transcript is present in hypothalamic neuroendocrine neurones and is released to the hypothalamicpituitary portal circuit. J Neuroendocrinol 15:219-226.

Lin L, Faraco J, Li H, Kadotani R, Rogers W, Lin X, Qui X, deJong PJ, Nishino S, Mignot E (1999) The sleep disorder canine narcolepsy is caused by a mutation in the hypocretin (orexin) receptor 2 gene. Cell 98:365-376.

Lu XY, Bagnol D, Burke S, Akil H, Watson SJ (2000) Differential distribution and regulation of OX1 and OX2 orexin/hypocretin receptor messenger RNA in the brain upon fasting. Horm Behav 37:335-2344.

Ma X, Zubcevic L, Brüning JC, Ashcroft FM, Burdakov D (2007) Electrical inhibition of identified anorexigenic POMC neurons by orexin/hypocretin. J Neurosci 27:1529-1533.

Marcus JN, Aschkenasi CJ, Lee CE, Chemelli RM, Saper CB, Yanagisawa M, Elmquist JK (2001) Differential expression of orexin receptors 1 and 2 in the rat brain. J Comp Neurol 435:6-25.

Münzberg H, Jobst EE, Bates SH, Jones J, Villanueva E, Leshan R, Björnholm M, Elmquist J, Sleeman M, Cowley MA, Myers MG Jr (2007) Appropriate inhibition of orexigenic hypothalamic arcuate nucleus neurons independently of leptin receptor/STAT3 signaling. J Neurosci 27:69-74.

Muroya S, Funahashi H, Yamanaka A, Kohno D, Uramura K, Nambu T, Shibahara M, Kuramochi M, Takigawa M, Yanagisawa M, Sakurai T, Shioda S, Yada T (2003) Orexins (hypocretins) directly interact with neuropeptide Y, POMC and glucose-responsive neurons to regulate $\mathrm{Ca} 2+$ signaling in a reciprocal manner to leptin: orexigenic neuronal pathways in the mediobasal hypothalamus. Eur J Neurosci 19:1524-1534.

Nishino S, Ripley B, Overeem S, Lammers GJ, Mignot E (2000) Hypocretin (orexin) deficiency in human narcolepsy. Lancet 355:39-40.

Parton LE, Ye CP, Coppari R, Enriori PJ, Choi B, Zhang CY, Xu C, Vianna CR, Balthasar N, Lee CE, Elmquist JK, Cowley MA, Lowell BB (2007) Glucose sensing by POMC neurons regulates glucose homeostasis and is impaired in obesity. Nature 449:228-232.

Peyron C, Tighe DK, van den Pol AN, de Lecea L, Heller HC, Sutcliffe JG, Kilduff TS (1998) Neurons containing hypocretin (orexin) project to multiple neuronal systems. J Neurosci 18:9996-10015.

Prasad BM, Conover CD, Sarkar DK, Rabii J, Advis JP (1993) Feed restriction in prepubertal lambs: effect on puberty onset and on in vivo release of luteinizing-hormone-releasing hormone, neuropeptide $\mathrm{Y}$ and betaendorphin from the posterior-lateral median eminence. Neuroendocrinology 57:1171-1181.

Russell SH, Small CJ, Dakin CL, Abbott CR, Morgan DGA, Ghatei MA, Bloom SR (2001) The central effects of orexin-A in the hypothalamicpituitary-adrenal axis in vivo and in vitro in male rats. J Neuroendocrinol 13:561-566.

Sakamoto F, Yamada S, Ueta Y (2004) Centrally administered orexin-A activates corticotropin-releasing factor-containing neurons in the hypotha- 
lamic paraventricular nucleus and central amygdaloid nucleus of rats: possible involvement of central orexins on stress-activated central CRF neurons. Regul Pept 118:183-191.

Sakurai T (2007) The neural circuit of orexin (hypocretin): maintaining sleep and wakefulness. Nat Rev Neurosci 8:171-181.

Sakurai T, Amemiya A, Ishii M, Matsuzaki I, Chemelli RM, Tanaka H, Williams SC, Richardson JA, Kozlowski GP, Wilson S, Arch JR, Buckingham RE, Haynes AC, Carr SA, Annan RS, McNulty DE, Liu WS, Terrett JA, Elshourbagy NA, Bergsma DJ, Yanagisawa M (1998) Orexins and orexin receptors: a family of hypothalamic neuropeptides and $\mathrm{G}$ protein-coupled receptors that regulate feeding behavior. Cell 92:573-585.

Samson WK, Taylor MM, Follwell MJ, Ferguson AV (2002) Orexin actions in hypothalamic paraventricular nucleus: physiological consequences and cellular correlates. Regul Pept 104:97-103.
Schwartz MW, Woods SC, Porte D Jr, Seeley RJ, Baskin DG (2000) Central nervous system control of food intake. Nature 404:661-671.

Spinazzi R, Andreis PG, Rossi GP, Nussdorfer GG (2006) Orexins in the regulation of the hypothalamic-pituitary-adrenal axis. Pharmacol Rev 58:46-57.

Thannickal R, Moore RY, Nienhuis R, Ramanathan L, Gulyani S, Aldrich M, Cornford M, Siegel JM (2000) Reduced number of hypocretin neurons in human narcolepsy. Neuron 27:469-474.

van den Pol AN, Gao XB, Obrietan K, Kilduff TS, Belousov AB (1998) Presynaptic and postsynaptic actions and modulation of neuroendocrine neurons by a new hypothalamic peptide, hypocretin/orexin. J Neurosci 18:7962-7971.

Willie JT, Chemelli RM, Sinton CM, Yanagisawa M (2001) To eat or to sleep? Orexin in the regulation of feeding and wakefulness. Annu Rev Neurosci 24:429-458. 